\title{
Species Identification of Mealie Meal Spoilage Organisms and Pathogenic Bacteria From Selected Food Stores in Lusaka District of Zambia.
}

Dayo Adeyemo ( $\square$ thinkerdy@gmail.com )

University of Zambia School of Veterinary Medicine https://orcid.org/0000-0003-1840-3759

Bernard Mudenda Hang’ombe

University of Zambia School of Veterinary Medicine

John Bwalya Muma

University of Zambia School of Veterinary Medicine

Musso Munyemme

University of Zambia School of Veterinary Medicine

\section{Data Article}

Keywords: Mealie Meal, Lusaka District, Food Safety, Spoilage Organisms, Pathogenic Bacteria

Posted Date: June 12th, 2020

DOI: https://doi.org/10.21203/rs.3.rs-34319/v1

License: (c) (1) This work is licensed under a Creative Commons Attribution 4.0 International License.

Read Full License 


\section{Abstract}

Mealie Meal is one of the by-products of maize from dry milling. It constitutes more significant part of the daily diet of growing population of the f Lusaka District of Zambia. However, reported cases of a cholera outbreak in October 2017-May 2018 were attributed to water contamination in the households of Lusaka. Hitherto there is no previous study or documented data for gastroenteritis caused by microbial contamination from food stores.

The main objective of the study was to carry out species identification of Mealie meal spoilage organisms and pathogenic bacteria from selected food stores in Lusaka district from September 2019 March 2020.Cross-sectional survey (prevalence study) was conducted for food spoilage organisms and pathogenic bacteria of packaged maize meal flour from a selected food store. The number of packaged Mealie meal samples from selected food stores included in the study was 143 samples. Samples were obtained by a simple stratified random selection from food stores in Lusaka District. Thus Mealie Meal samples bought from Street food vendors were 96 (67\%), Shops-30 (21\%), Malls-17 (11.9\%). Subsequently isolation by spread and pour plate methods, and species identification of microbial contamination by Cell Culture processes coupled to microbial morphological and biochemical characterization was performed. Microsoft Office Excel (version 2007) Spreadsheet was employed for the categorical data analysis and summarized graphical presentation of data. The preliminary laboratory findings revealed the following: Spoilage organisms - Aspergillum species, Mucor Species, Candida Species, Clostridium Species and Bacillus Species; Pathogenic Bacteria Species-Clostridium perfringens, Staphylococcus aureus, Clostridium tetani , Bacillus, Escherichia coli, Pseudomonas aeruginosa and Yesinia pestis.It can be established from the laboratory results earlier mentioned that the food poisoning outbreak could evolve from food stores in Lusaka district apart from water contamination.

\section{Introduction}

Globally, food safety is of great public health concern from farm to fork. The invasion of microbial contaminants into foodstuff is determined by microbial controlling factors for growth and survival. These include intrinsic, extrinsic and implicit factors. Intrinsic factors could be moisture content, $\mathrm{pH}$ and acidity, biological structure, Redox potential, naturally occurring and added antimicrobials needed for growths. Also extrinsic and implicit factors involve types of packaging material, gases at ambient or sub-ambient pressures, storage temperatures and time, reaction to stress after exposure to existing enzymes and membrane proteins, and presence of heat shock respectively [1]. Therefore proper environmental sanitation and hygiene practice of the household dwellers, especially during rainy season, serve as determinants of food safety and culminate the invariably in prevention of food borne diseases. In the Lusaka District of Zambia, Mealie Meal is a staple diet enjoyed with varieties of relish. It is popularly called Breakfast (or Nshima when cooked) by the residents of Lusaka district. The microbial contaminants of Mealie Meal from retail outlets have never been studied or reported in Lusaka District. 
Hence in this study, we intend to examine (by microbiological analysis) microbial contaminations derived from packaged Mealie meal purchased from selected food stores in Lusaka District.

\section{Material and Methods:}

Study Design, Location and Sampling:

2.1Study Design and Sample Size:

A cross-sectional survey (prevalence study) was conducted from September2019 - March 2020 for food spoilage organisms and pathogenic bacteria of packaged maize meal flour from selected food stores. There was no data on the prevalence of microbiological contamination of the Mealie Meal in Zambia. To estimate the prevalence within $5 \%$ allowable error and considering a $95 \%$ confidence level, the calculation will be based on the assumption that $50 \%$ of the maize flour samples collected from Food stores in Lusaka district have microbial contamination [2]. Thus the number of packaged mealie meal samples from selected Food Stores included in the study was 143 samples.

\subsection{Study Location}

In the Lusaka district of Zambia, food stores are situated around the low, medium and high population density [3]. Thus Lusaka district was mapped out into five study areas namely: South, Central, East, West and North. Food stores in each area were further randomly stratified into sampling units of interest: mall, shop and street food vendor as shown in Fig. 1.

Mealie Meal, popularly known as Breakfast by Lusaka Household dwellers, is all but available in every food store at varying weight and sizes in a containing bag. Intending consumers could also obtain ready to cook size from plastic containers peddled by street food vendors.

\subsection{Sample Collection:}

143 Packaged Mealie Meal of different brands was bought from selected food stores (Street food vendor, Shops and Malls) of each study area. Samples were obtained by a simple stratified randomly selection from Food Stores in Lusaka District. Thus Mealie Meal samples bought from Street food vendors were 96 (67\%), Shops-30 (21\%), Malls-17 (11.9\%). The representative samples were transported in packaged plastic bags with label, and stored at ambient temperature in the Biosafety Laboratory of the Department of Disease Control, School of Veterinary Medicine, University of Zambia, before laboratory investigations.

\section{2.4Laboratory Methods:}

2. 2.5Microbiological Analysis of Packaged Mealie Meal Samples:

For all collected samples, 25 grams of mealie meal was mixed with fifty $\mathrm{ml}$ of distilled water in containing bottle, and allowed to settle for 2 hours. $10 \mathrm{mls}$ of the supernatant was centrifuged at 
$3000 \mathrm{rpm}$ for 10 minute. For Clostridia and Stapyloocous specie, eight $\mathrm{ml}$ of Brain heart infusion broth (BHIB) was added to the precipitate, which was heated for germination at $808 \mathrm{C}$ for $10 \mathrm{~min}$. This was then sub cultured to BHIB and incubated anaerobic ally in the BBL anaerobic jar at $378 \mathrm{C}$ for $48 \mathrm{~h}$ [4]. For other organisms, serial dilutions (10 - 1 to $10-5)$ were prepared and plated in triplicate into each specific medium. Aliquots, $0.1 \mathrm{ml}$ and $1 \mathrm{ml}$, of each dilution were used for spread plating and poured plating respectively, into the various media (AMPH, 2001). To detect and characterize other spoilage and pathogen bacteria, standard method ajar was employed and incubated at 37 degrees centigrade for 24 hours. Representative sample colonies based on cultural characteristics were inoculated into nutrient broth (Merck HG000C42) at $37^{\circ} \mathrm{C}$ over night and streaked into the nutrient slant for further analysis (Morton, 2001). Coli forms were cultured on eosin methylene blue media, incubated at $37^{\circ} \mathrm{C}$ for $24-48 \mathrm{~h}$. Bacillus cereus was cultured using Macconkey agar, which was incubated at $37^{\circ} \mathrm{C}$ for $24 \mathrm{~h}$. For spoilage fungi organisms, yeast and mold were cultured on Sabround Dextrose Agar. The plates were incubated at $25^{\circ} \mathrm{C}$ for 7 days. Consequently Gram-stained smears of the different cell colonies were identified from slides by Olympia light microscope.

\subsection{Statistically Analysis:}

Experimental data collected were analyzed using Chi-square. The statistical significance was defined at $\mathrm{P}<0.05$.

\section{Material And Methods}

\section{Study Design, Location and Sampling:}

\subsection{Study Design and Sample Size:}

A cross-sectional survey (prevalence study) was conducted from September2019 -March 2020 for food spoilage organisms and pathogenic bacteria of packaged maize meal flour from selected food stores. There was no data on the prevalence of microbiological contamination of the Mealie Meal in Zambia. To estimate the prevalence within $5 \%$ allowable error and considering a $95 \%$ confidence level, the calculation will be based on the assumption that $50 \%$ of the maize flour samples collected from Food stores in Lusaka district have microbial contamination [2]. Thus the number of packaged mealie meal samples from selected Food Stores included in the study was 143 samples.

\subsection{Study Location}

In the Lusaka district of Zambia, food stores are situated around the low, medium and high population density [3]. Thus Lusaka district was mapped out into five study areas namely: South, Central, East, West and North. Food stores in each area were further randomly stratified into sampling units of interest: mall, shop and street food vendor as shown in Figure 1.

Mealie Meal, popularly known as Breakfast by Lusaka Household dwellers, is all but available in every food store at varying weight and sizes in a containing bag. Intending consumers could also obtain ready 
to cook size from plastic containers peddled by street food vendors.

\subsection{Sample Collection:}

I43 Packaged Mealie Meal of different brands was bought from selected food stores (Street food vendor, Shops and Malls) of each study area. Samples were obtained by a simple stratified randomly selection from Food Stores in Lusaka District. Thus Mealie Meal samples bought from Street food vendors were 96 (67\%), Shops-30 (21\%), Malls-17 (11.9\%). The representative samples were transported in packaged plastic bags with label, and stored at ambient temperature in the Biosafety Laboratory of the Department of Disease Control, School of Veterinary Medicine, University of Zambia, before laboratory investigations.

\subsection{Laboratory Methods:}

2.5Microbiological Analysis of Packaged Mealie Meal Samples:

For all collected samples, 25 grams of mealie meal was mixed with fifty $\mathrm{ml}$ of distilled water in containing bottle, and allowed to settle for 2 hours. $10 \mathrm{mls}$ of the supernatant was centrifuged at 3000 rpm for 10 minute. For Clostridia and Stapyloocous specie, eight ml of Brain heart infusion broth (BHIB) was added to the precipitate, which was heated for germination at $808 \mathrm{C}$ for $10 \mathrm{~min}$. This was then sub cultured to BHIB and incubated anaerobic ally in the BBL anaerobic jar at $378 \mathrm{C}$ for $48 \mathrm{~h}$ [4]. For other organisms, serial dilutions (10-1 to 10-5) were prepared and plated in triplicate into each specific medium. Aliquots, $0.1 \mathrm{ml}$ and $1 \mathrm{ml}$, of each dilution were used for spread plating and poured plating respectively, into the various media (AMPH, 2001). To detect and characterize other spoilage and pathogen bacteria, standard method ajar was employed and incubated at 37 degrees centigrade for 24 hours.

Representative sample colonies based on cultural characteristics were inoculated into nutrient broth (Merck HG000C42) at $37^{\circ} \mathrm{C}$ over night and streaked into the nutrient slant for further analysis (Morton, 2001). Coli forms were cultured on eosin methylene blue media, incubated at $37^{\circ} \mathrm{C}$ for $24-48 \mathrm{~h}$. Bacillus cereus was cultured using Macconkey agar, which was incubated at $37^{\circ} \mathrm{C}$ for $24 \mathrm{~h}$. For spoilage fungi organisms, yeast and mold were cultured on Sabround Dextrose Agar. The plates were incubated at $25^{\circ} \mathrm{C}$ for 7 days. Consequently Gram-stained smears of the different cell colonies were identified from slides by Olympia light microscope.

\subsection{Statistically Analysis:}

Experimental data collected were analyzed using Chi-square. The statistical significance was defined at $\mathrm{P}<0.05$.

\section{Results And Discussion}

\section{Results and Discussion:}


3.1 Mealie Meal Spoilage and Pathogenic Bacteria Species identified from Selected Food Stores Lusaka District are shown in Table 1 below.

Table 1

\begin{tabular}{|llll|}
\hline $\begin{array}{l}\text { Mealie } \\
\text { Meal }\end{array}$ & Street Food Vendor & Shop & Mall \\
\hline $\begin{array}{l}\text { Spoilage } \\
\text { Bacteria }\end{array}$ & $\begin{array}{l}\text { Clostridium } \\
\text { Perfringens,Bacillus } \\
\text { Cereus }\end{array}$ & $\begin{array}{l}\text { Clostridium } \\
\text { Perfringens }\end{array}$ & No growth \\
\hline $\begin{array}{l}\text { Pathogenic } \\
\text { Bacteria }\end{array}$ & $\begin{array}{l}\text { Clostridium Tetani, } \\
\text { Bacillus Cereus, } \\
\text { Clostridium }\end{array}$ & $\begin{array}{l}\text { Staphylocoous } \\
\text { Aureus and }\end{array}$ & $\begin{array}{l}\text { Clostridium Tetani, Staphylococcus } \\
\text { Aureus, *Gram-ve rods - Escherichia } \\
\text { coli, Pseudomonas aeruginosa, }\end{array}$ \\
& $\begin{array}{l}\text { Perfringens and } \\
\text { *Gram-ve rods- }\end{array}$ & $\begin{array}{l}\text { *Gram-ve rods- } \\
\text { Escherichia coli, }\end{array}$ & Yesinia pestis species. \\
& $\begin{array}{l}\text { Escherichia coli, } \\
\text { Pseudomonas } \\
\text { Peruginosa, Yesinia }\end{array}$ & \\
& $\begin{array}{l}\text { aeruginosa, Yesinia } \\
\text { pestis species. }\end{array}$ & pestis species. & \\
\hline
\end{tabular}

Spoilage and Pathogenic Bacteria species in the mealie meal depicted in Table 1 reflected the natural habitat of the source of the sample, survival property (spore-forming), and storage facilities. Clostridium Perfringens, Clostridium Tetani and Bacillus Cereus species identified are of soil ecology. Besides they can withstand unfavorable conditions for microbial growth with their spores. Gram -ve rods such as $\mathrm{E}$ coli, Pseudomonas and Yesrsia pestis are also identified due to different storage facilities that enhanced enabling environment for growth. Only Staphylococcus aureus species detected for shop and mall. It indicates cross-contamination possibly from the food handlers or workers while there was no presence of spoilage bacteria identified from mall.

3.2 Mealie Meal Spoilage and Pathogenic Bacteria Species identified after Boiling at $100 * \mathrm{C}$ in Water Bath shown the Fig. 2 Below: These are casual organisms for Food Poisoning Outbreak as a result of their toxic products. They are Bacillus species, Clostridium Perfringens species, Clostridium Tetani species and Staphylococous Aureus. It shows they can survive in the cooking process.

\subsection{Scheme for Mealie Meal Pathogenic Bacteria Species identified:}

International Commission on Microbiological Specification for Foods (ICMSF) devised a scheme for sampling which incorporates a 2-class plan and 3 -class plan. The 2-class plan provides presence or absence criteria for an intestinal pathogen. The 3-class plan is based on enumeration levels (Colony counting) of the general bacterial flora. It takes into account maximum and minimum levels [5].For this research; we adopt the 2-class plan and also grouped the food -borne pathogens into three categories according to the degree of hazard. 
Table 2

\begin{tabular}{|ll|}
\hline Degree of Hazard & Food -borne Pathogens \\
\hline Severe, often fatal & Clostridium perfringens \\
\hline $\begin{array}{l}\text { Moderate with potential } \\
\text { for spread }\end{array}$ & $\begin{array}{l}\text { Gram-ve rods-( Colifroms) Escherichia coli, Pseudomonas aeruginosa, } \\
\text { Yesinia pestis species }\end{array}$ \\
\hline $\begin{array}{l}\text { Moderate with limited } \\
\text { spread }\end{array}$ & Bacillus cereus and Staphylococci \\
\hline
\end{tabular}

\subsection{Spoilage Fungi identified from Selected Food Stores.}

Table 3

\begin{tabular}{|llll|}
\hline Spoilage Organisms & Street Food Vendor & Shop & Mall \\
\hline Mold & Mucor species & Mucor species & Mucor species \\
\hline Mold & Aspergillum species & Aspergillum & Aspergillum species \\
\hline Yeast & Candida species & & Candida species \\
\hline
\end{tabular}

Spoilage Fungi species identified from selected food stores are common spoilage organisms of raw maize. It includes Species of Mold - Mucor, Aspergillum, and Yeast- Candida respectfully.

Interestingly - enough, only Mealie meal specimen from shop identified no spoilage organism derived from yeast.

List of Mealie Meal Spoilage Organisms and Pathogenic Bacteria identified from Selected Food Stores in Lusaka District as compiled in Table 4 shown below.

Table 4

\begin{tabular}{|c|c|c|c|}
\hline $\begin{array}{l}\text { Mealie } \\
\text { Meal }\end{array}$ & Street Food Vendors & Shops & Malls \\
\hline $\begin{array}{l}\text { Spoilage } \\
\text { Organisms }\end{array}$ & $\begin{array}{l}\text { Mucor ,Aspergillum, Clostridium } \\
\text { Perfringens, Bacillus species }\end{array}$ & $\begin{array}{l}\text { Mucor ,Aspergillum, Clostridium } \\
\text { Perfringens, Bacillus species }\end{array}$ & $\begin{array}{l}\text { Mucor, } \\
\text { Aspergillum, } \\
\text { Candida }\end{array}$ \\
\hline $\begin{array}{l}\text { Pathogenic } \\
\text { Bacteria }\end{array}$ & $\begin{array}{l}\text { Clostridium perfringens, } \\
\text { Bacillus, Staphylococcus } \\
\text { Aureus Species, Gram-ve rods- } \\
\text { Escherichia coli, Pseudomonas } \\
\text { aeruginosa, Yesinia pestis } \\
\text { Species }\end{array}$ & $\begin{array}{l}\text { Clostridium perfringens, } \\
\text { Bacillus, Staphylococcus } \\
\text { Aureus species, Gram-ve rods- } \\
\text { Escherichia coli, Pseudomonas } \\
\text { aeruginosa, Yesinia pestis } \\
\text { species }\end{array}$ & $\begin{array}{l}\text { Clostridium } \\
\text { Perfringens, } \\
\text { Staphylococcus } \\
\text { Aureus }\end{array}$ \\
\hline
\end{tabular}

From the available laboratory results in Table 4, it is evident that food borne disease could evolve from selected food stores in Lusaka District. Hence Food safety of the household dwellers of Lusaka District is threatened by the invasion of spoilage organisms and pathogenic bacteria detected by microbiological analysis of mealie meal specimens examined in the laboratory. 


\section{Conclusions}

Mealie Meal Microbial contaminants could invade the Food Stores as illustrated by the schematic diagram shown:

Figure 3 Schematic Diagrams for Food Safety \& Microbial Contaminants

Therefore proper environmental sanitation and hygienic practice of the household dwellers of Lusaka District must be enhanced, especially during the rainy season, as shown from the above diagram. It would serve as determinants of food safety and culminate invariably in the prevention of food borne diseases from microbial contaminants. Microorganisms may be introduced from food handlers in the restaurant, canteen, shops and malls or at home during the preparation of the Mealie meal. Raw foods can also bring food poisoning organisms into kitchens may contaminate processed foods directly or by transfer of the microorganisms via hands, surfaces and equipment. Poisonous substances may be produced by the growth of bacteria and moulds in food. Other sources of harmful substances must not be overlooked. Therefore food should be nourishing and attractive. It must be visibly clean, and it must also be free from noxious material. These harmful substances may be poisonous chemicals and even chemical harmless in small amounts, but damaging in large quantities. They may enter the food accidentally during preparation or accumulate in the food during storage in metal containers [6]. The typical example is aflatoxin. Aflatoxins are poisonous carcinogens and mutagens. They are by-product of molds (Aspergillum and Aspergillum parasitic us) that grow in soil, decaying vegetation, hay, and grains (maize). A study conducted in Kenya and Mali found that the predominant practices for drying and storage of maize were inadequate in minimizing exposure to aflatoxins [7]. It has been observed that children are susceptible to aflatoxin exposure, which is associated with stunted growth, delayed development milestones and liver cancer [8]. These cases could be reported in the Lusaka district in the near future.

\section{Declarations}

\section{Availability of data and materials:}

The available data generated from the experimental results are included in the study.

\section{Funding:}

Africa Centre of Excellence for Infectious Diseases of Humans and Animals

Authors' contributions: Not Applicable

\section{Conflicts of Interest:}

The authors declare no conflicts of interest regarding publication for this paper. 
Acknowledgement:

My sincere appreciate is unlimited for the encouragement and worthwhile efforts of my supervisors, Professor Bernard Ham `ombe and Professor John Muma. Their contributions were the guiding principles for this research study.

Authors` information: Not Applicable

\section{References}

1. Hamg'ombe Bernard Mudenda (2019) APPLIED FOOD MICROBIOLOGY AND NUTRITIONAL TOXICOLOGY MODULE LECTURE, School of Veterinary Medicine, University of Zambia, Lusaka, Zambia.

2. Wilma, Nchito, An Analysis of the location of Markets in Lusaka, 42nd ISoCaRP Congress 2006 Paper, Page 5-6

3. 10.1186/s12995-015-0077-2 Mwamungule Susan J Muma and Malama S (2015)Contamination of health care workers'coats at the University Teaching Hospital in Lusaka, Zambia: the nosocomial risk Journal of Occupational Medicine and Toxicology (2015) 10:34 DOI 10.1186/s12995-015-0077-2

4. Bernard Mudenda Hang'ombea, Emiko Isogaib,Josphat Lungua, Charles Mubitaa, Andrew Nambotac,Rikio Kirisawad

Bernard Mudenda Hang'ombea, Emiko Isogaib,Josphat Lungua, Charles Mubitaa, Andrew Nambotac,Rikio Kirisawad, Kimurae K, Isogai H (2000).Detection and characterization of Clostridium Species in soil of Zambia Comparative Immunology, Microbiology \& Infectious Diseases 23 (2000) $277 \pm 284$

5. Betty C, Hobbs, Roberts D (1987).Food Poisoning and Food Hygiene fifth Edition AISE, 1987, Page 281-282

6. Betty C, Hobbs, Roberts D (1987).Food Poisoning and Food Hygiene fifth Edition AISE, 1987, Page 17

7. Tiongco M, Mahuku G, de Groote H, Hellin J, Bett C, Kenya / KARI, Nzioki H, and S. Collins (2015\}.No chance for Aflatoxin, Way Back Machine The International Journal for Rural Development October 17 (2015) www.rural21.com/english/news/detail/article/no-chance-for-aflatoxins-0000656

8. Khlangwiset P, Shephard GS, Wu F (October (2011)) "Aflatoxins and growth impairment: a review". Critical Reviews in Toxicology. 41 (9): 740-55. doi:10.3109/10408444.2011.575766. PMID 21711088.

\section{Figures}




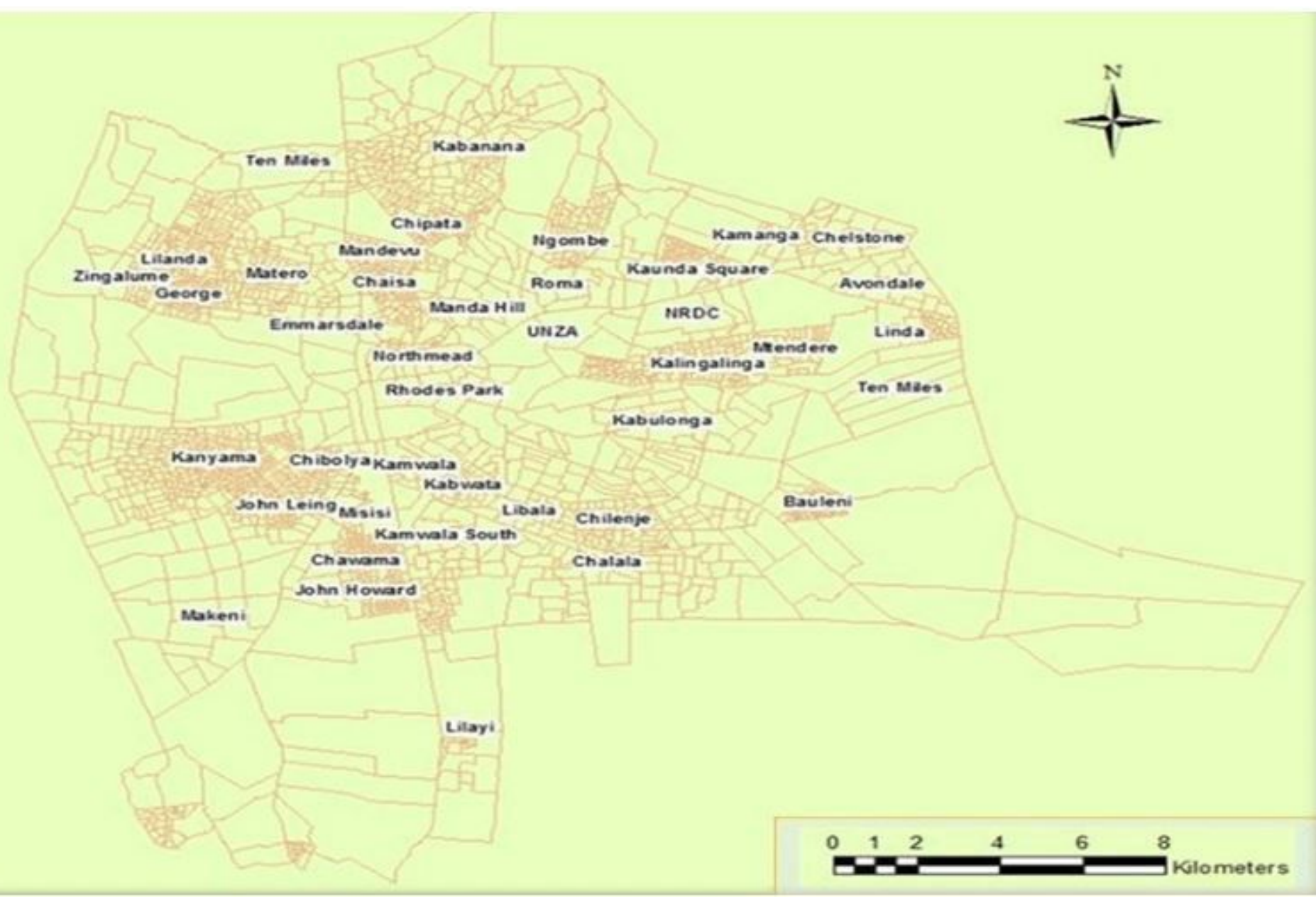

Figure 1

Map of Lusaka District.

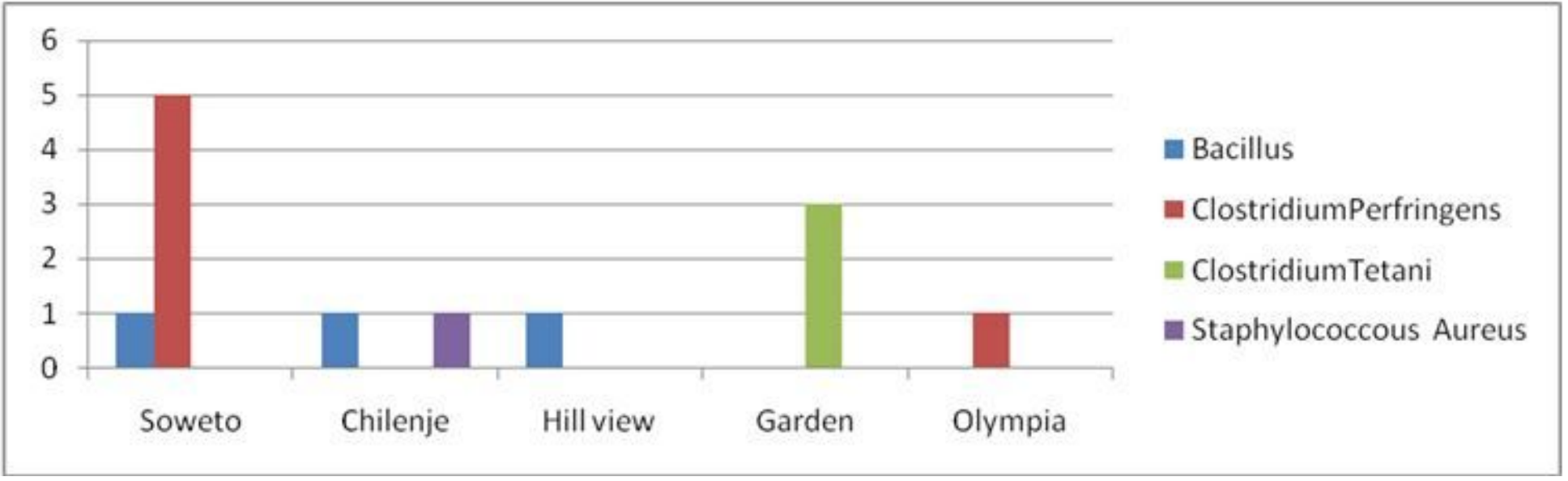

Figure 2

Causal Organisms identified from Mealie Meal. 


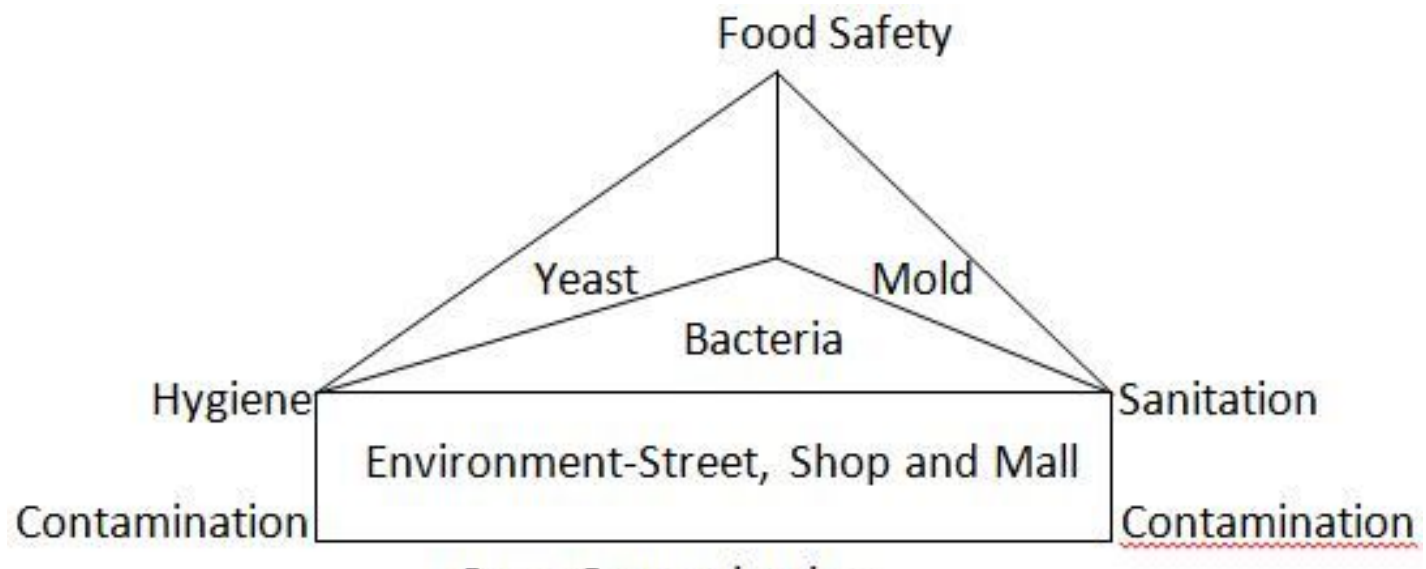

Cross Contamination

Figure 3

Schematic Diagrams for Food Safety \& Microbial Contaminants 